\title{
Evaluation on Public Goal, the Challenge for Successful Management of the Public Drinking Water Treatment in Albanian Condition
}

\author{
Prof Assoc Dr Alba Dumi \\ Dean of graduated School "Ismail Qemali"Vlora University, Albania \\ Email:besi.alba@yahoo.com \\ Ma Arlinda Velaj \\ University of Tirana, Faculty of Foreign Languages, German Language Branch \\ arlinda.velaj@yahoo.com \\ Ma Estela Çobo \\ Master School"Ismail Qemali"Vlora University, Albania \\ Estelacobo21@gmail.com
}

Doi: 10.5901/mjss.2013.v4n4p269

\section{Abstract}

The most important element of this reform in the public sector is the incentive related to the reformation of the public administration. This process is necessary to face the challenges and to have better services with few sources possible. The public services are oriented by the input. The structures and the organizational procedures are created in order to involve the employees and need efforts and contribution from them. In the public service department the results are considered as a product of the efforts and staff's capacities. The requirement of these results is lead by an inspirational vision, which is a clear mission and has some strategic aims, and these aims are transformed in objectives which aim to improve the performance. The market in Albania is full of low cost, high quality real estate for sale. There are literally thousands of brand new, great value apartments, houses and offices on sale now at unbelievable prices. Even in the best locations, such as the capital Tirana, or the coastal metropolis of Durrës there are fantastic bargains to take advantage of when it comes to buying Albanian real estate. From rural homesteads, to palatial urban apartments, there's property for sale in Albania to suit the needs of every potential investor, all at prices that can't be beaten - not even in neighbouring countries. Property in Albania is great value beyond belief! Having long been overlooked by investors, Albanian properties are now beginning to be snapped up by savvy foreigners looking for a good deal. Albania is a rapidly developing economy, on the path to European integration, and as such is a safe bet for a healthy return on your investment.

Keywords: Globalization, Drinking water, Individual performance, Challenges, Strategic aims, Albenian drinking water problems, Administrative performance

\section{Introduction}

Globalization has opened new avenues for both employers and job seekers. One off-shoot of this is the practice of outsourcing jobs (hiring lower-paid service workers in foreign countries to do work previously done by higher-paid workers) has been a contentious issue in high-income countries, especially the United States. Many American citizens dispute this industry trend because it takes away jobs from Americans, while others dispute it for the ethical implications of exploiting overseas workers. But even in high-income countries like the United States, millions of workers earn minimum wage at full-time jobs and still cannot afford basic necessities. (Staw, B.M \& Ross, J)

Sanitation presents even more problems than drinking water. Sanitation coverage in urban areas is almost the same as drinking water coverage. Urban areas have mostly combined sewage and storm water collection networks that discharge into near bay surface water-bodies. About $40 \%$ of the urban population has a sewer connection. (Vroom, V.H \& Yetton references)

In rural areas, only a small portion of the areas with piped water supply is equipped with sever networks. Most rural areas have individual household wastewater collection systems, principally simple pit-latrines with no drainage pipes. 
Upgrading of sewer networks hasn't kept pace with the general development of infrastructure, and the materials and technology used haven't been improved. Presently, there's no treatment of wastewater in Albania; its discharge in water bodies, especially in coastal tourist areas and delicate ecosystems, is a major environmental concern for the government/business/community/wide public.

\subsection{Albania and real state situation for sale}

The market in Albania is full of low cost, high quality real estate for sale. There are literally thousands of brand new, great value apartments, houses and offices on sale now at unbelievable prices. Even in the best locations, such as the capital Tirana, or the coastal metropolis of Durrës there are fantastic bargains to take advantage of when it comes to buying Albanian real estate. From rural homesteads, to palatial urban apartments, there's property for sale in Albania to suit the needs of every potential investor, all at prices that can't be beaten - not even in neighbouring countries. Property in Albania is great value beyond belief!

Having long been overlooked by investors, Albanian properties are now beginning to be snapped up by savvy foreigners looking for a good deal. Albania is a rapidly developing economy, on the path to European integration, and as such is a safe bet for a healthy return on your investment. The evaluation of individual performance has always been an element for the motivation of the employees of the public administration and the increase of its performance. In this study there are efforts done to point out some problems of the evaluation of individual performance as a part of the organization's culture, which affects the increase of efficiency and consists of the key for a successful management of the public administration.

\subsubsection{Albania and water distribution water problem}

Albania faces a water distribution problem, not a water production problem. Studies indicate that available sources of supply could provide more than enough to satisfy the country's overall water demand. In many cities, water availability at the source is about 500-700 litres per capita per day, but leaks and waste mean that only a small fraction of water produced is consumed. Almost everywhere problems of water scarcity can be considerably mitigated through metering, leakage detection and reduction, network improvements, disconnection of illegal connections, and optimization of storage and supply patterns. (Stogdill, R.M 2009)The distribution problem also has a seasonal aspect: much more water is needed during the summer growing season; when rainfall is scarce, rural drinking water is often misused for irrigation; and the tourist resort areas use large amounts of water.

The main issues handled out in this presentation are: strengthening local government leadership and initiative; partnership between municipalities and NGOs; concluding all of these in the community-based approaches to infrastructure services and neighbourhood revitalization.

\subsection{Climate change and the world view}

And when people are forced to work for low wages in poor working conditions, workplace safety and health is severely compromised. Another facet of this phenomenon is the need for creation of sustainable livelihoods which has become an important factor in the present day world, especially in developing countries and among disadvantaged populations. Sustaining the progress calls for an explicit consideration of future generations. Youth will inherit many of the environmental, economic and social problems created over the past decades and incorporating their opinions and concerns into policies at all levels is critical for a country's progress. ( Vroom, V.H \& Yetton references)

\section{Literature Review and Hypotheses}

In many countries of Europe the public sector is going through a deep reformation. Improving performance, better services, time spent on the assignments realization, the responsibility and the effectiveness of the programs and public services, are very important to everybody, for the persons who offer these services and for the ones who receive it. But there are a lot of political, bureaucratic and technical hindrances that affect the performance of the Public Administration.

Globalisation also stands as a major cause for unequitable distribution of Resources. Women and children are the major sufferers and are the most economically disadvantaged of all groups. The Earth's climate is changing and its atmosphere is warming.( Stogdill, R.M) What might this mean for freshwater resources? 
- $\quad$ Rising water demands. Hotter summers mean thirstier people and plants. Temperature increases will likely contribute to higher water demands. In addition, more evaporation from reservoirs and irrigated farmland will lead to faster depletion of water supplies;

- Increased drought. Scientific evidence suggests that rising temperatures in the southwestern United States will reduce river flows and contribute to an increased severity, frequency, and duration of droughts;

- Seasonal supply reductions. Many utilities depend on winter snowpack to store water and then gradually release it through snowmelt during spring and summer. Warmer temperatures will accelerate snowmelt, causing the bulk of the runoff to occur earlier-before crops can use the water-and potentially increasing water storage needs in these areas;

- Long-term water supply reductions. Many communities depend on seasonal water runoff from glaciers. Although shrinking glaciers create higher runoff (and thus more water) in the short term, the longer-term disappearance of glaciers threatens this important water resource.

Although private organizations may not have direct voting power in what mix of organizations is chosen to implement the plan, they could very well influence how the public and its elected and appointed representatives make these choices. (Vroom, V.H \& Yetton references)

Decentralization has given local governments the discretion and scope they need to take a lead role in responding to the challenges of economic downturn, degradation of the urban environment, and social hardship. They institute bold initiatives and innovative practices. (Yukl, G.A 2001)Western European nations have put in place sophisticated frameworks to provide local governments with technical and financial assistance. The European Union supplements these national programs with coordinated assistance aimed at promoting economic development, assisting distressed localities and fostering social inclusion. Infrastructure is an important component of these programs.

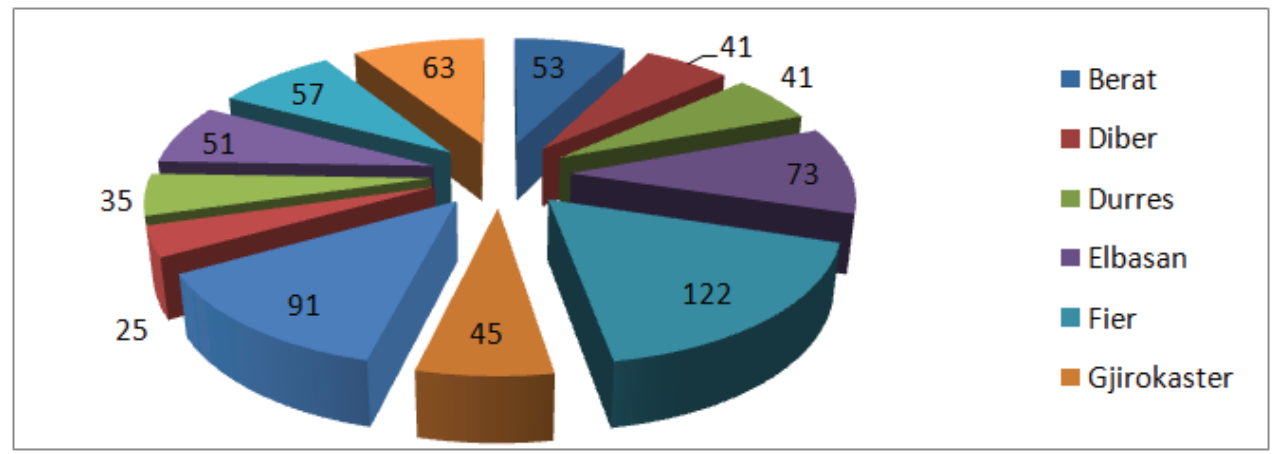

Tab 1: Water quality problems and issues are both local and regional as evidenced by a variety of reports included in, (Hydric Management, London 2011

In strong local government leadership and active community participation were key to implementing an integrated plan involving urban planning, infrastructure, and economic development. Despite its location in an industrialized province Jerez's economy relies on wine production which, in recent years has been declining. ( Staw, B.M \& Ross, J1980)

Reservoirs even out the fluctuations in a water supply by storing water when it is abundant and releasing it later, especially when water supply diminishes during drought.

Identify advances in detection, monitoring and modelling, analytical methods, information needs and technologies, research and development opportunities, and communication strategies that will enable the water supply industry and other stakeholders to further reduce risks associated with public water supply distribution systems.

Water towers, a familiar sight along nearly every highway in America, help to make sure that water deliveries remain relatively constant even during peak water use times. Their main purpose, however, is to elevate the water level high enough to supply adequate water pressure throughout a distribution system. Water quality assessments are in charge of the Department of Environmental Protection (PADEP), and testimony received by the committee. Some of these water quality problems are associated primarily with urbanization vicinity; some are associated with activity in the Allegheny River basins; still others are common to the predominantly rural counties. 
Large differences exist among the sources of problems, their potential effects on Albanian public health and environmental quality, and their likely solutions. (Sereness, G.AJERM Journal 2012)

Further, resolution of water quality issues is affected by other regional issues such as transportation, land use, and governance of the metropolitan area.

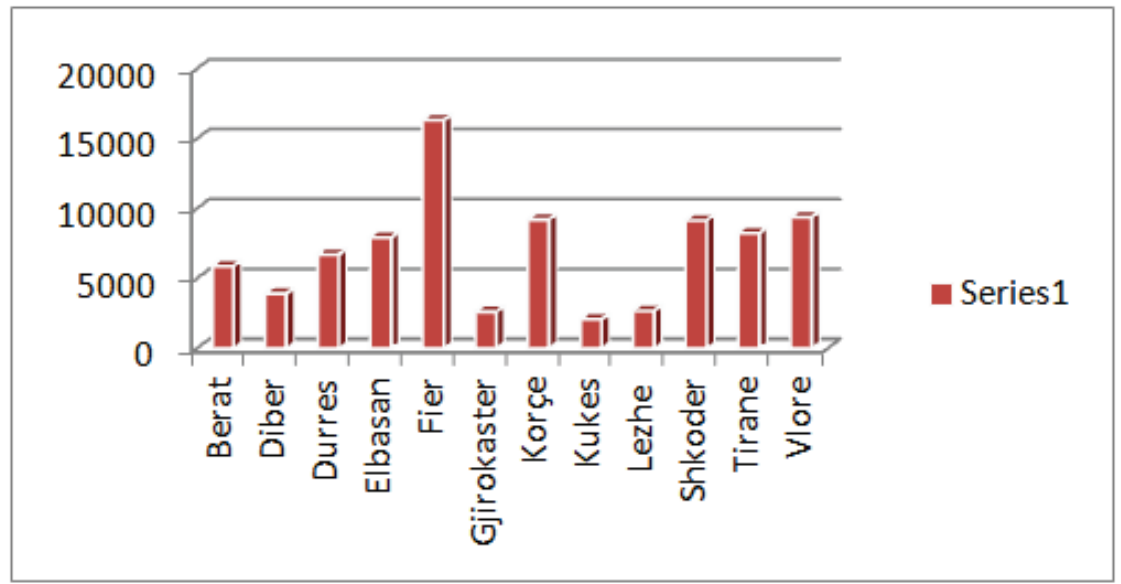

Tab 2: The resolution of water quality distribution in Albanian region, Source: MOE year 2012

Thinking about your local reservoir may conjure visions of water sports, fishing, or picnicking, but reservoirs serve a much more vital purpose. Reservoirs, or man-made lakes, are typically created by building dams across rivers (some also occur naturally).

\subsection{An historical sight of the evalution system in Albania}

During the last decade the Albanian Public Administration is going under a reformation process, a process related with the political, economical and social changes.

At the beginning of the ' 90 the role of the Albanian state was modernized, and was stimulated to economic improvement and to conceal social injustice. Small hydro is gaining ground across the Balkans. The small (municipal) Albanian investor is looking for medium-size hydro and dam companies who know how to tap special funds. (Quinn, R.E. Spreitzer, G.M)

This has been traditionally the arena of big players such as Siemens with specific staff to handle the World Bank, the European Investment Bank and the EBRD. The Balkans show small funding is happening. Brussels and USAID also have small technical funds in the agricultural sector which can mesh nicely with reservoir building for irrigation and domestic water projects. American banks are also very active in Albania.(Dumi A JERM 2012)

The performance evaluation is a process that makes the employees reflect, discuss and change their working methods. During the process the individuals can change their working methods and there may be changes even in their behavior. At the institutional level the process enables the systematic collection of data about the individual's performance.

\section{Methodology and Research Goal}

The extensive use of reservoirs for fish production as part of food security is expanding exponentially. There is a market for expertise on protecting big volumes of fish at the turbines, as well as fish ladders and other bypass schemes. (Quinn, R.E 1989)Reservoir stocks for the market attract EU funding and may be worth tens of millions of Euros. Food ministers want clean river basin waters reaching the sea which will not damage high value shellfish beds and fish breeding grounds.

The significance of this is reflected in tensions between Italy, Croatia, Slovenia and Albania over their coastal stocks. One side of the Adriatic is only about $148 \mathrm{~km}$ from the other, so the potential for pollution from the land is very 
high. In 1993 fertiliser land runoff coated 600km of the Yugoslav to Italian coastline with toxic algae. This cost several billion Euros in today's money through lost fish and collapsed tourism. (Quinn, R.E. Spreitzer, G.M)

The existing pattern of water supply and water quality services in the region is highly fragmented, with more than 1,000 providers operating in the multicounty region area, like many other metro areas in the United States, large-special purpose authorities such as the Allegheny County Sanitary Authority (ALCOSAN) can achieve substantial economies of scale through joint management agencies.

\subsection{Data and methodology of study in this paper research}

This article was made created by respecting all the methodological rules. The methodology of this article was based in two parts: Studying the foreign and Albanian literature, bibliographic studies, collecting data from official sources as MOE, ISKSH Albania, MOH, DHR Resources and from different publications such as magazines. And practicing, which is related with the interviews with leaders and employees of the Public Administration. To collect the data for this article we made interviews, questionnaires and other researches. We created also a questionnaire, which was composed by 130 questions and $5.8 \%$ of the employees in the central level of the public administration answered. We are concluding in these seven key factors for success, such as:

- A dynamic local government leadership

- A coherent strategy acted upon with determination

- A healthy climate of cooperation with business

- Local government's investment initiatives to jumpstart the stagnant economy

- Creative use EU funds to implement local policy

- Efficient municipal administration

- Coherent links among urban planning, infrastructure and economic development

\begin{tabular}{|c|c|c|c|c|c|}
\hline & & & & & \\
\hline First choice & 12 & 18 & 37 & 59 & \\
\hline Second choice & 42 & 71 & 52 & 63 & 44 \\
\hline
\end{tabular}

The respective evaluations are presented below:

\subsection{Analyzing data and regression analyze}

The performance evaluation is mainly characterized by qualitative indicators and there are only a few quantitative indicators. According to the data collected from the questionnaires the employees asses the importance of the performance evaluation in $200 \%$, they concretize it with the objectivity in the evaluation.

\begin{tabular}{|c|c|c|c|c|c|c|c|c|c|}
\hline values & $\underline{4}$ & $\underline{4}$ & $\underline{5}$ & $\underline{6}$ & $\underline{7}$ & 7 & 7 & 8 & 9 \\
\hline Ranks & 1 & 2 & 3 & 4 & 5 & 6 & 7 & 8 & 9 \\
\hline
\end{tabular}

$M_{R}=\frac{n 1(n 1+n 2+1)}{2}=\frac{4(4+5+1)}{2}=$ The variance is to from seven to nine $\{7,9\}$

We calculate the quadratic average derivation of the Man Whitney criteria

$\mathrm{S}_{\mathrm{R} 1}=\sqrt{\frac{n 1 n 2(n 1+n 2+1)}{12}}$

To the question "Is the performance evaluation objective in your institution?"- $30 \%$ answered positively, $64 \%$ avoided the answer and $36 \%$ of them think that it is dictated from the subjectivity of the leaders. According to the questionnaire the major part of the questioned employees think that the performance evaluation takes to conflicts between the subordinate and the superiors. This is also another factor that contests rewarding according to the performance. (Yukl, G.A)

We calculate the factual value $\mathrm{Zf}$ and is compared with $\mathrm{Zk}$ that is the statistic value at a critic level.

$Z f=\left(R_{1 m}-M_{R}\right) / S R_{1}=(30-20) / 4.8=2$ The variance is to from seven to nine $\{7,9\}$

$Z f>Z k ; 2>1.76$ The variance is to from seven to nine $\{1,7-9,78\}$ 
This calculation shows that the hypothesis is not valid.

In the performance evaluation the subjectivism has high levels. It is important to find other parameters for the evaluation, and this is a commitment of this article in the future.

\subsection{Albanians NGO development strategy}

In Tirana sustained population growth since 1991-1999 led to rapid expansion of the urbanized area, resulting $\mathrm{n}$ the proliferation of informal settlements. With an estimated population of 575.000 in 1997, 6.500 families were seeking new housing each year. Local government, even with central transfers, could accommodate only five percent of the demand for new infrastructure.

Supported by donor assistance and international and local NGO's the city initiated a community-based development strategy in the informal settlement .The program brought together local government teams, NGO's and residents to formulate a development plan for the neighborhood define priorities for improvements and determine equitable cost-sharing formulas to finance infrastructure. In 1992- 1999, the city's Urban Planning unit decided to initiate participatory process to rehabilitate and revitalize the districts. The process required an extensive outreach effort, involving consultations with every household.

Regularly scheduled public meetings were held and gradually residents became aware of the role they could play in shaping the future of their neighborhood. In December 1993 the city council adopted a new strategy to stimulate local investment in infrastructure and buildings based on partnership between the city and the residents.

The act for support of local investment committed the municipality to cover 50 percent of the cost of water, sewerage and power lines, 70 percent of the cost of roadbeds and sidewalks and 100 percent of the cost of drainage and street paving. The cost sharing formula can be modulated to take into consideration issues of equity and cost burden. As an incentive to private rehabilitations of buildings, investors are granted a three year exemption from property taxes.During the years 1994 - 1999 in Albania the partnership between the municipality and the residents was institutionalizes through the Local Initiatives Program to ensure its continuity as a citywide development strategy.

The key features of the program are:

1. Introducing participatory planning and community-based development processes through neighborhood development committees and street representatives working in partnership with the city

2. Creating an enabling environment for private investment

3. Empowering citizens to pursue their own self improvement

4. promoting privatization of the housing a stock and fostering the development of micro- enterprises

5. Ensuring the sustainability of activities initiated

6. Promoting the reliability of successful initiatives.

This process allowed the canton to build consensus, prepare a development plan, allocate municipal funds equitably leverage additional resources and improve infrastructure and living conditions. The participatory municipal management improve infrastructure and living conditions.

The results from this article show that the performance evaluation is a very important element in the Public Administration, and it effects the improvement of the work in the state and central bodies.

- The performance evaluation conditions the emplacement and the implementation of the standards as referential points. Emplacing standards would increase the responsibility for each post in the Public Administration and will help in monitoring the performance of the institution. Lack of access to land and the on going process of fragmentation of family holdings have led to widespread poverty, prompting out migration.To meet these daunting challenges, the canton democratized its planning and management procedures. This process allowed the canton to build consensus, prepare a development plan, allocate municipal funds equitably leverage additional resources and improve infrastructure and living conditions. The participatory municipal management improve infrastructure and living conditions. The participatory municipal management process was institutionalizes ensuring representation of women and marginalizes groups.

\section{Recomandation and conclusions:}

1. Introducing participatory planning and community-based development processes through neighborhood development committees and street representatives working in partnership with the city

2. Creating an enabling environment for private investment

3. Empowering citizens to pursue their own self improvement 
4. promoting privatization of the housing a stock and fostering the development of micro- enterprises

5. Ensuring the sustainability of activities initiated

6. Promoting the reliability of successful initiatives.

Albanian government will be reality these points:

- A dynamic local government leadership

- A coherent strategy acted upon with determination

- A healthy climate of cooperation with business

- Local government's investment initiatives to jumpstart the stagnant economy

- Creative use EU funds to implement local policy

- Efficient municipal administration

\section{References}

Quinn, R.E. Beyond rational management.Mastering the paradoxes and competing demands of high performance. San Francisco: Jossey-Bass, 1988.

Quinn, R.E. Spreitzer, G.M \& Hart, S. Challenging the assumptions of bipolarity: interpenetration and managerial effectiveness. In S.Srivastva and R. Fry (eds). Executive continuity San Francisco, CA: Jossey-Bass, 1991.

Schlenker, B.R. Impression management: the self-concept, social identity and interpersonal relations.Monterey,CA: Brooks/Cole Publishing Company, 1980.

Staw, B.M \& Ross, J. Journal of Applied Psychology, 1980, 65(3), 249-260.

Stogdill, R.M. personal factors associated with leadership: A survey of the literature. Journal of psychology, 1948/, 25, 35-71.

Van Fleet, D.D \& Yukl, G.A. military leadership: an organizational behavior perspective. Greenwich, CT: JAI Press, 1986.

Vroom, V.H \& Yetton, E.W. Leadership and decision making. Pittsburgh University Press, 1973.

Wheaton, B. Assesment of fit in overidentified models with latent variables. In J.s. Long (ed), Common problems/propers solutions: Avoiding error in quantitative research. Beverly Hills, CA: Sage, 1988.

Yukl, G.A. A New Taxonomy for Intergrating Diverse Perspectives On Managerial Behavior. Paper presented at the American Psychological Association meeting, New York, 1987.

Yukl, G.A. leadership in organization. Englewood Cliffs, NJ: Prentice-Hall, 1989. (a)

Zaccaro, S.J, Foti, R.J \& Kenny, D.A. Self-monitoring and trait-based variance in leadership: An investigation of leader flexibility across multiple team situations. Journal of Applied Psychology, 1991, 76(2), 308-315. 
